\title{
Targeting the androgen receptor: improving outcomes for castration- resistant prostate cancer
}

\author{
Howard I Scher, Grant Buchanan ${ }^{1}$, William Gerald ${ }^{2}$, Lisa M Butler ${ }^{1}$ \\ and Wayne D Tilley ${ }^{1}$
}

\author{
Genitourinary Oncology Service, Division of Solid Tumor Oncology, Memorial Sloan-Kettering Cancer Center \\ Department of Medicine, Joan and Sanford I Weill College of Medicine, New York, New York 10021, USA \\ ${ }^{1}$ Dame Roma Mitchell Cancer Research Laboratories, Department of Medicine, University of Adelaide \\ \& Hanson Institute, Adelaide SA 5000, Australia \\ ${ }^{2}$ Department of Pathology, Memorial Sloan-Kettering Cancer Center, New York, New York 10021, USA
}

(Requests for offprints should be addressed to Howard I Scher, Memorial Sloan-Kettering Cancer Center, 1275 York Avenue, New York, New York 10021, USA; Email: scherh@mskcc.org or Wayne Tilley, The Hanson Institute, PO Box 14 Rundle Mall, Adelaide SA 5000, Australia; Email: wayne.tilley@adelaide.edu.au)

\begin{abstract}
The categorization of prostate cancers that are progressing after castration as 'hormone-refractory' evolved from the clinical observation that surgical or medical castration (i.e. androgen ablation therapy; AAT) is not curative and, despite an initial response, virtually all tumors eventually regrow. Successful AAT is contingent on the dependence of prostate cancer cells for androgen signaling through an intracellular mediator, the androgen receptor (AR) for survival. Current preclinical and clinical data imply that the AR is expressed and continues to mediate androgen signaling after failure of AAT. As AAT does not completely eliminate circulating androgens, sufficient concentrations of dihydrotestosterone may accumulate in tumor cells to maintain AR signaling, especially in the context of upregulated receptor levels or increased sensitivity of the AR for activation. In addition, ligands of non-testicular origin or ligand-independent activation can contribute to continued AR signaling. In many cases, therefore, from the perspective of the AR, a 'hormone-refractory' classification after failure of AAT is inappropriate. Classifying prostate tumors that progress after AAT as 'castration-resistant' may be more relevant. Clinical responses to second- and third-line hormonal therapies suggest that the mechanisms of AR activation are in part a function of previously administered AAT. Accordingly, the increasing trend to utilize AAT earlier in the course of the clinical disease may have a greater influence on the genotype and phenotype of the resistant tumor. In this article, we detail strategies to inhibit the growth of prostate cancer cells that specifically target the AR in addition to those practiced traditionally that indirectly target the receptor by reducing the amount of circulating ligand. We propose that treatment regimes combining AAT with direct AR targeting strategies may provide a more complete blockade of androgen signaling, thereby preventing or significantly delaying the emergence of treatment-resistant disease.
\end{abstract}

Endocrine-Related Cancer (2004) 11 459-476

\section{Introduction}

The demonstration that exogenous estrogens or surgical orchidectomy could produce tumor shrinkage in the advanced disease setting ushered in the era of hormonal management of prostate cancer in 1941 (Huggins \& Hodges 1941, Huggins et al. 1941). Benefits to the patient included palliation of pain and relief of urinary symptoms, with a concomitant decline in acid phosphatase concentrations, consistent with the clinical findings. The success of hormone treatment, or more specifically of androgen ablation therapy (AAT), is contingent on the dependence of prostate cancer cells on the more potent $5 \alpha$-reduced metabolite of testosterone, $5 \alpha$-dihydrotestosterone (DHT), for their growth and survival. The traditional view of hormones and the prostate is therefore 


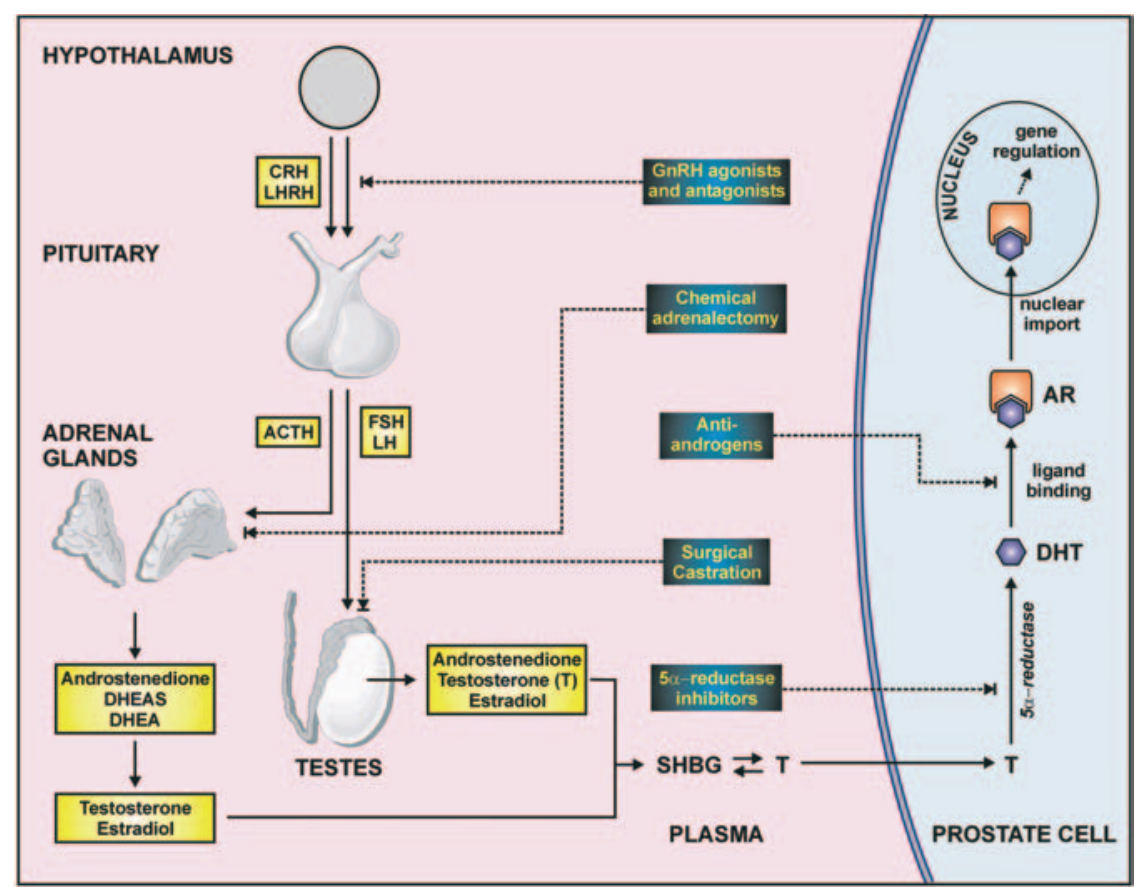

Figure 1 Endocrine control of prostatic growth. The growth and development of the normal prostate requires a functioning androgen signaling pathway, which is regulated by the hypothalamic-pituitary-gonadal axis. Androgens [testosterone ( $T$ ), androstenedione, dehydroepiandrosterone (DHEA)] and other steroids are synthesized in the testes or adrenal glands and released into the circulation in response to specific hormonal signals [adrenocorticotropic hormone $(\mathrm{ACTH})$, corticotropin-releasing hormone $(\mathrm{CRH})$, follicle stimulating hormone $(\mathrm{FSH})$, gonadotropin releasing hormone $(\mathrm{GnRH})$, luteinizing hormone $(\mathrm{LH})$, luteinizing hormone releasing hormone (LHRH)]. Testosterone is transported by steroid hormone binding globulin (SHBG) to the prostate, where it is predominantly converted, by $5 \alpha$-reductase, to its more active metabolite, $5 \alpha$-dihydrotestosterone (DHT). In the prostate, androgens mediate their effects via high-affinity binding to the androgen receptor (AR), a nuclear transcription factor that controls expression of genes involved in growth, differentiation, homeostasis and apoptosis. Medical and surgical interventions commonly used to treat prostate cancer (i.e. androgen ablation therapy) are indicated by dotted lines at the point in which they disrupt the androgen signaling pathway.

focused on the ligand, and in particular on reducing or blocking the action of DHT (Fig. 1). DHT binds to and activates the androgen receptor (AR), which regulates transcription of a diverse range of target genes involved in prostate cell homeostasis, angiogenesis, differentiation and apoptosis (Buchanan et al. 2001b, Gelmann 2002, Tilley et al. 2003).

In the modern era, the clinical use of AAT has been expanded to include medical therapies such as luteinizing hormone-releasing hormone (LHRH) agonists/antagonists or estrogens that target the hypothalamic-pituitary-gonadal axis (Fig. 1). Combined androgen blockade strategies utilize LHRH agonists/antagonists and AR antagonists to inhibit respectively the production of testicular androgens and the binding of residual androgens to the AR (Labrie et al. 1983). Enzymatic inhibitors of adrenal synthetic enzymes are used to block the production of adrenal androgens. The common feature of these approaches is that they target the receptor indirectly, by (i) reducing circulating concentrations of the native ligand (i.e. testicular androgens) either medically or surgically, or (ii) blocking the ability of androgens to bind to the AR using receptor antagonists. Although these strategies were originally used to treat patients with metastatic disease, clinical use of AAT expanded to the neoadjuvant (before primary treatment) and, more commonly, to the adjuvant (during primary treatment) setting in combination with surgery or radiation, in addition to conditions of increasing prostate specific antigen (PSA) concentrations (no detectable disease on an imaging study). However, irrespective of the nature and timing of AAT, overall outcomes are similar: an initial response, then a period of stability, followed by biochemical, radiographic and, ultimately, clinical progression. What is not clear, however, are the mechanisms contributing to the failure of AAT. In particular, whether renewed growth of prostate tumors is the result of maintenance of AR signaling in a castrate setting or of activation of AR-independent survival pathways, is a topic of considerable debate. In this review, we develop 


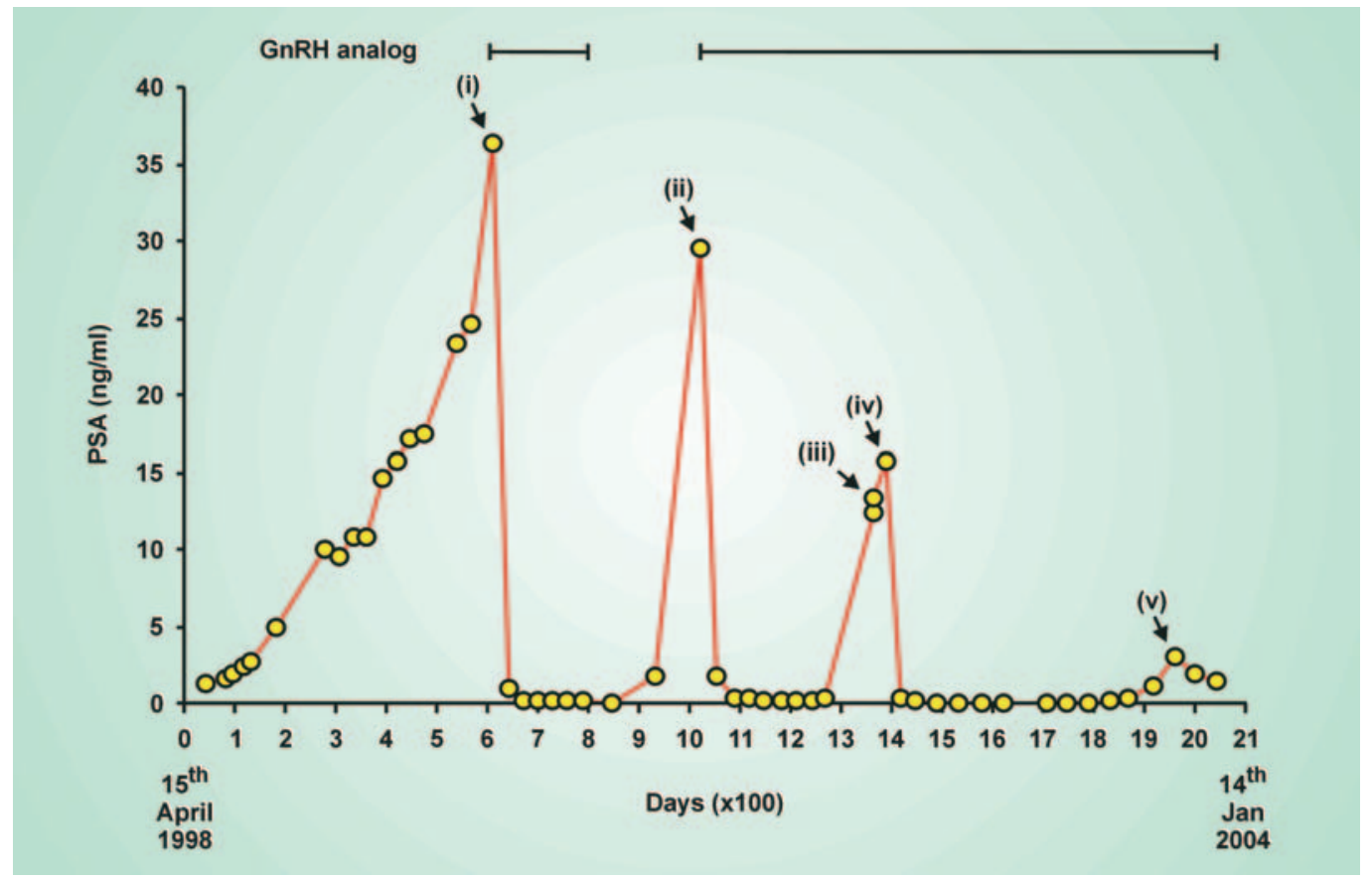

Figure 2 An example of a sequential hormonal response. A clinical example of sequential decreases in PSA concentration, associated with no progression in other sites such as bone, lymph nodes or viscera, and no new symptoms of disease, in a patient treated (i) with 6 months of a GnRH analog and bicalutamide (as indicated), and then (ii) a second course of combined blockade. At the time of progression, (iii) bicalutamide was discontinued with no response, following which (iv) nilutamide was added, producing a decline in PSA for more than 8 months. Later, an increase in PSA was noted, at which point (v) nilutamide was discontinued, with a tertiary response.

the case for the persistence of AR-dependent signaling mechanisms after failure of AAT, suggest novel strategies using existing hormonal treatments for prostate cancer, and discuss new therapies that directly target the AR, which may be more effective than conventional androgen ablation.

\section{Evidence for maintenance of AR signaling after failure of AAT}

\section{Clinical studies}

Prostate cancers that progress despite castrate concentrations of testosterone in the blood have been categorized as 'hormone-refractory', implying that further hormonal treatments would be of limited clinical value. That PSA concentrations increase in virtually all cases of resistance to AAT argues against this categorization, because signaling is mediated through a specific androgen response element in the promoter of the PSA gene (Balk et al. 2003). Further evidence against a hormonerefractory categorization is the observation that more than $20-40 \%$ of prostate tumors that progress on AAT respond to second- and third-line hormonal treatments (Kojima et al. 2004). These therapies include anti- androgens, estrogens, progestational agents, inhibitors of adrenal steroid synthesis such as ketoconazole and glucocorticoids (Scher et al. 1995, Small 1997). The paradoxical responses to the discontinuation of antiandrogens, estrogens, glucocorticoids and progestational agents (Kelly \& Scher 1993, Scher \& Kelly 1993, Wirth \& Froschermaier 1997), and disease flares that occur when exogenous androgens are administered (Fowler \& Whitmore 1981, Manni et al. 1988), are additional illustrations of continued hormonal sensitivity despite failure of AAT.

Anti-androgen withdrawal responses have been documented in more than $30 \%$ of patients who received flutamide as part of a combined androgen blockade approach (Scher et al. 1995). Secondary clinical responses to bicalutamide observed in patients who have progressed on flutamide independent of a withdrawal response (Scher \& Kolvenbag 1997), and the PSA response to nilutamide in patients with a previous anti-androgen withdrawal response, provide additional evidence of hormone sensitivity (Kassouf et al. 2003). A clinical example of secondary and tertiary responses to different androgen ablations is shown in Fig. 2. This patient was treated initially with a 6-month course of a gonadotropinreleasing hormone $(\mathrm{GnRH})$ analog and bicalutamide, 


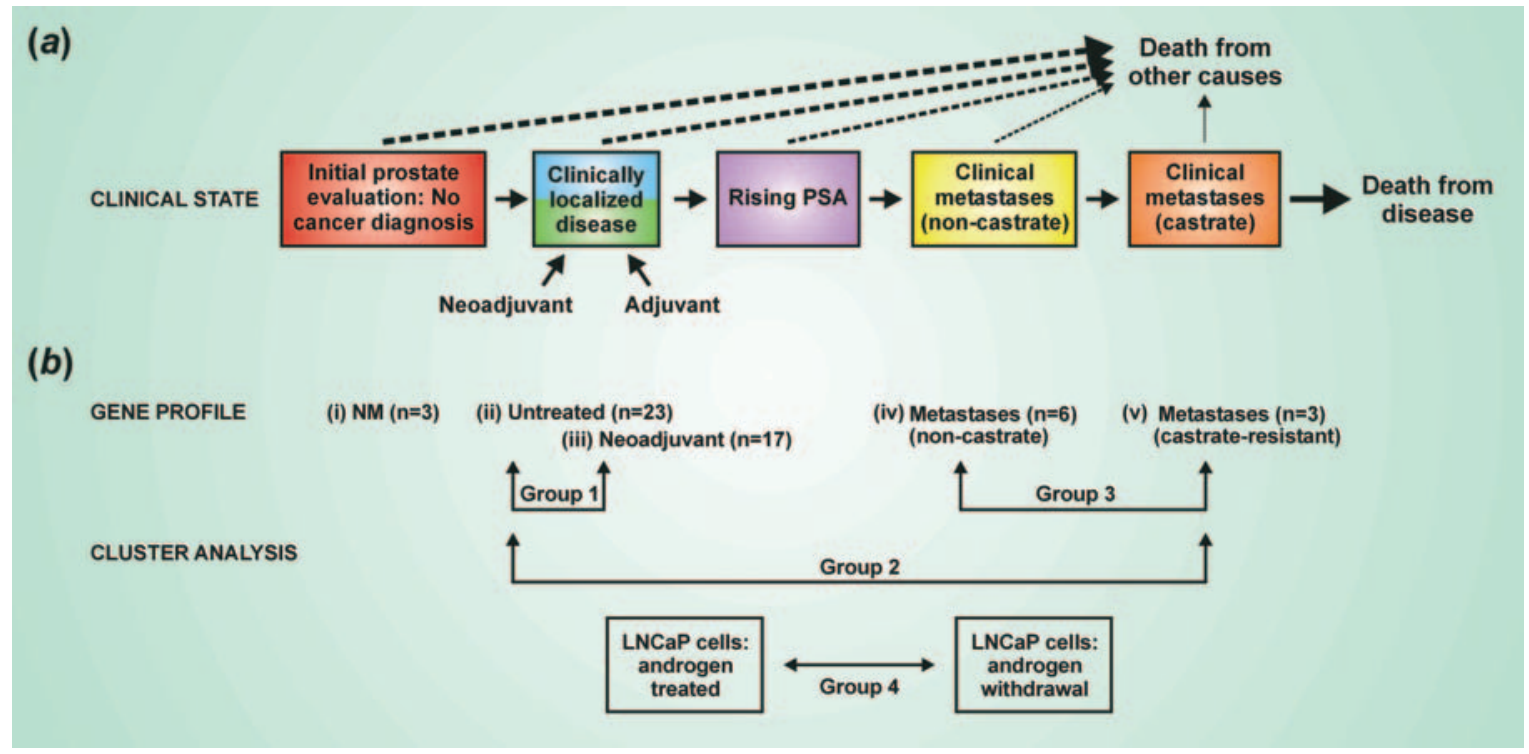

Figure 3 (a) Clinical states: a framework with which to define treatment objectives, to select treatment and to assess outcomes. Based on recognizable points in the natural history of prostate cancer, key milestones or clinical states that apply to an individual or to a population can be defined. This stratification provides a framework for defining therapeutic objectives, disease management and understanding the basis of progression. As more men die with prostate cancer than from it, effective management relies on determining which state a patient resides in at a given point of time, and assessment of the probability that a patient will progress to castration-resistant metastatic disease before dying of other causes. Androgen ablation traditionally was used to treat metastatic disease. More recently, androgen deprivation has been used in a neoadjuvant setting (before primary treatment), but is more commonly used in an adjuvant setting (during primary treatment) for clinically localized disease when an increasing PSA is first documented. The longer the duration of treatment in an adjuvant setting, the more likely that the specific hormone therapy administered will affect the biology of the progressing tumor. (b) Profiling of gene expression in primary and castrate-resistant prostate tumors. Microarray and tissue array studies were conducted on clinical prostate cancer samples, which were chosen from the clinical states indicated in (a), using procedures approved by the Institutional Review Board of the Memorial Sloan-Kettering Cancer Center. Malignant and benign regions were microdissected from (i) 3 non-cancerous prostates (NM) and 49 prostate tumors, the latter consisting of (ii) 23 untreated primary tumors, (iii) 17 primary tumors after neoadjuvant AAT, (iv) 6 metastatic tumors and (v) 3 recurrent metastatic tumors after androgen ablation. mRNA was extracted from each sample and from the human prostate cancer cell line, LNCaP, stimulated with $0.1 \mathrm{nM} \mathrm{R} 1881$, a synthetic androgen, for $24 \mathrm{~h}$ and either harvested immediately or incubated in steroid-free conditions for a further $36 \mathrm{~h}$ to simulate androgen withdrawal. Gene expression profiling was performed on mRNA samples with Affymetrix U95 human gene arrays using instruments and procedures as described previously (Holzbeierlein et al. 2004). To identify differentially expressed genes, comparisons between three tumor groups were performed: Group 1, (ii) versus (iii); Group 2, (ii) versus (v); Group 3, (iv) versus (v), as indicated. Similarly, comparisons were made between LNCaP cells cultured with or without androgens. Differential expression was defined as a minimum of threefold difference between expression of selected genes.

after which all treatment was discontinued. When the PSA increased, combined androgen ablation was reinstituted on a continuous basis until the PSA increased again and bicalutamide was discontinued. No response to bicalutamide discontinuation was observed, but the addition of nilutamide resulted in a decline in PSA concentrations for more than 8 months. Later, an increase in PSA was noted, at which time nilutamide was discontinued and the PSA declined again.

Immunohistochemical and other studies of clinical tumor samples have demonstrated that the AR is expressed in the majority of AAT-naïve and -resistant tumors, and that the tissue concentrations of PSA and other androgen-responsive genes increase in the setting of castration-resistant tumor growth (Hobisch et al. 1995,
Bentel \& Tilley 1996, Culig et al. 1998). To investigate overall changes in gene expression during progression of clinical prostate cancer after androgen ablation, we undertook microarray gene profiling of both naïve and AAT-treated primary prostate cancers removed by radical prostatectomy, and castration-resistant metastatic tumors (Fig. 3) (Holzbeierlein et al. 2004). As expected, many of the genes with altered expression in primary tumors removed 3 months after initiation of androgen deprivation, and those in LNCaP cells after androgen manipulation, included known targets of the androgen receptor (e.g. KLK3, KLK2; Fig. 4a). Significantly, the gene expression profile of castration-resistant metastatic tumors is similar to that of hormone-naïve lesions, but quite distinct from that of primary tumors after 
(a)

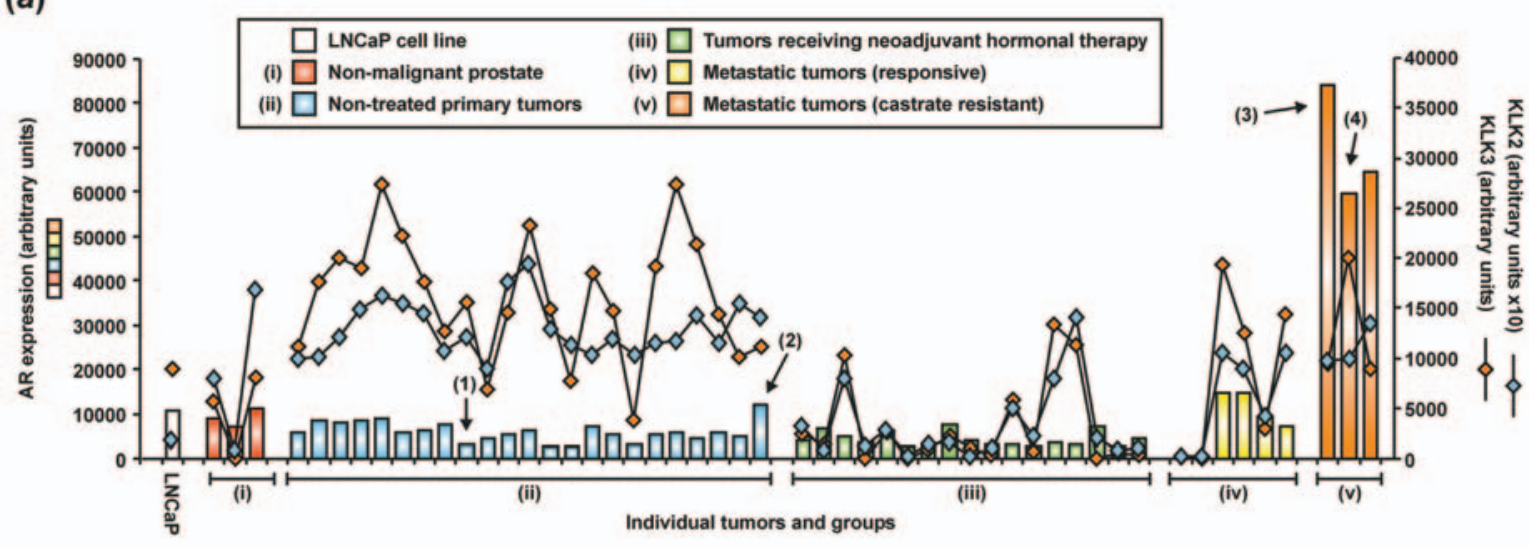

(b)
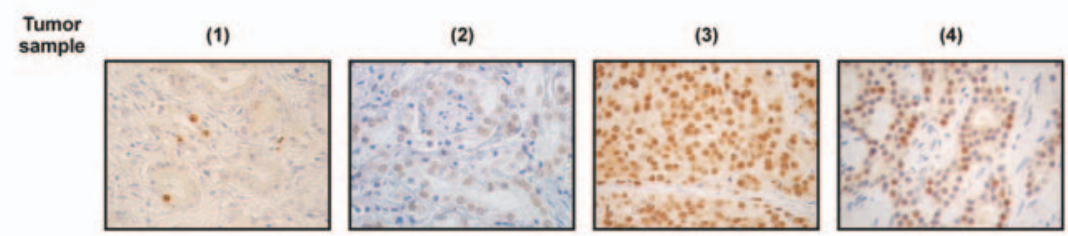

Figure 4 AR expression is increased in castrate-resistant prostate cancer. (a) Gene expression of $A R$ and the androgen-responsive kallikreins, KLK2 and KLK3, determined from Affymetrix array profiling experiments (refer to Fig. 3) for each of the prostate tumor groups. (b) Multi-tissue blocks of formalin-fixed, paraffin-embedded tissue corresponding to the same benign and malignant prostate samples analysed in (a) were prepared using a tissue arrayer (Beecher Instruments, Silver Spring, MD, USA). The multi-tissue blocks included three representative $0.6 \mathrm{~mm}$ cores of each sample derived from diagnostic regions. Immunohistochemical staining for AR was carried out with standard streptavidin-biotin peroxidase methodology using formalin-fixed, paraffin-embedded tissue and microwave antigen retrieval (LaTulippe et al. 2002).

short-term androgen ablation. Approximately $97 \%$ of the genes with altered expression after neoadjuvant AAT were not altered in castration-resistant tumors (e.g. KLK3, KLK2; Fig. 4a). The median level of AR expression was markedly increased (9-11-fold) in castration-resistant metastatic disease (Mann-Whitney $U$ test; $P=0.028)$ relative to untreated or neoadjuvant-treated primary tumors (Fig. 4a). Immunohistochemical analysis confirmed that AR RNA levels were concordant with the amount of receptor protein in individual tumor samples (Fig. 4b). These data strongly suggest that prostate tumors evolve mechanisms to reactivate AR expression and AR-responsive gene pathways after AAT, and that these changes have a key role in the development of resistance to hormonal treatment (Amler et al. 2000, LaTulippe et al. 2002, Holzbeierlein et al. 2004).

\section{Animal studies}

The CWR22 xenograft is an androgen-dependent tumor derived from a patient with metastatic prostate cancer grown subcutaneously in athymic nude mice (Pretlow et al. 1993, Wainstein et al. 1994, Nagabhushan et al. 1996, Tan et al. 1997). After androgen ablation, these tumors show regression, stability and later progression, similar to what is seen in the human condition. In most animals, castration-resistant CWR22 tumors emerge after 80-200 days after androgen withdrawal (Nagabhushan et al. 1996). A marked reduction in the expression of AR and markers of cellular proliferation is observed in CWR22 tumors two days post-castration (Agus et al. 1999). However, subsequent proliferation during tumor regrowth is associated with re-expression of $\mathrm{AR}$ and androgen-regulated genes to levels comparable to those seen in tumors from intact mice (Gregory et al. 1998, Agus et al. 1999, Kim et al. 2002). Expression profiling of AAT-naïve and castration-resistant CWR22 tumors demonstrated that the expression of only a small proportion of genes $(<5 \%)$ was altered in the recurrent tumors (Amler et al. 2000). Collectively, these studies suggest that restoration of AR signaling pathways is associated with renewed growth of CWR22 tumors in a castrate environment. More recently, Chen and colleagues (2004), who compared the gene expression profiles of 
isogenic androgen withdrawal-sensitive and -resistant xenograft tumors, demonstrated that, from seven human prostate cancer xenografts examined, the AR was the only gene consistently upregulated in castration-resistant tumors.

\section{Mechanisms of continued AR signaling during progression}

Studies of androgen-mediated signaling in animal models and human tumor specimens must be interpreted in the context of the point in the illness that the tumor sample represents. Different results will be obtained depending on the stage of disease, whether the sample was from the prostate or a particular metastatic site, whether the tumor has or has not been exposed to a specific form of androgen deprivation and whether it is proliferating (i.e. the disease is progressing) or non-proliferating (i.e. regressing or static). All these states are difficult to characterize, because human tumor samples often are not obtained in the course of routine medical management after diagnosis. Nevertheless, as discussed above, the findings of recent studies support the concept that AR signaling is maintained or upregulated in tumors that regrow after failure of $\mathrm{AAT}$, and that the associated activation of androgen-regulated genes is sufficient to facilitate tumor survival. The specific alterations in prostate tumor cells that facilitate increased sensitivity of the AR signaling pathway can be considered at the level of the ligand and the receptor, the structure and function of the AR and its coregulators, or cross-talk with other signaling pathways (Fig. 5) (Tilley et al. 1996, Grossmann et al. 2001).

\section{Increased bioavailability of ligand}

Whereas testosterone and DHT concentrations in the blood are low in a patient whose tumor is progressing after castration, intratumoral androgen concentrations may be sufficient to maintain tumor growth (Labrie et al. 1983, Geller et al. 1984a,b, Mohler et al. 2004). Tumor cells may acquire mechanisms to accumulate androgens, such as sequestration by steroid hormone binding globulin, which is synthesized and secreted by prostatic epithelial and stromal cells (Hryb et al. 2002), or by altered regulation of enzymes involved in the synthesis and metabolism of androgens. In support of this hypothesis, the comparative microarray analysis detailed above detected increased expression of enzymes in the steroid precursor synthesis pathway in castration-resistant tumors compared with that in castration-naïve samples (Holzbeierlein et al. 2004). These enzymes included 3hydroxy-3-methylglutaryl-coenzyme A synthase 1 and squalene epoxidase, which are considered to be ratelimiting enzymes in sterol biosynthesis (Chugh et al. 2003). Genes involved in fatty acid and steroid metabolism, which potentially could facilitate steroid production, were also upregulated. Recently, Mohler and coworkers (2004) measured the concentrations of AR and androgens in the tissues of locally recurrent prostate cancers after AAT. Similar concentrations of testosterone were detected in recurrent tumor samples and in control benign prostatic hyperplasia specimens. Moreover, whereas the concentrations of DHT, dehydroepiandrosterone and androstenedione were lower in recurrent prostate tumor tissues than in benign prostatic hyperplasia samples, there was a sufficient concentration of ligand to account for the expression of the AR-regulated PSA protein. These results ague that, despite androgen ablation, prostate tumors may never encounter a completely 'androgen-independent' environment (Mohler et al. 2004).

\section{AR expression}

Immunohistochemical studies demonstrate that the AR is expressed in essentially all human prostate cancers, including those that regrow after failure of AAT, and that the level of AR expression is at least retained, and often increased, relative to untreated tumors (e.g. Fig. 4) (Sadi \& Barrack 1993, Pertschuk et al. 1994, Tilley et al. 1994, Takeda et al. 1996, Culig et al. 1998, Prins et al. 1998, Mohler et al. 2004). One mechanism for increased receptor concentrations is amplification of the AR gene, which has been reported in $22 \%$ of castration-resistant metastatic tumors, and in 23-28\% of recurrent primary tumors (Bubendorf et al. 1999). AR gene amplification is associated with increased concentrations of the AR and AR-regulated proteins (Koivisto et al. 1996, 1997, Koivisto \& Helin 1999, Linja et al. 2001). Only eight castrationresistant tumors of 28 examined $(29 \%)$ in our independent studies exhibited amplification of the AR gene, whereas 26 of the $28(93 \%)$ overexpressed the AR protein (Holzbeierlein et al. 2004). Increased concentrations of AR in prostate tumors could result from increased AR protein stability, as observed in recurrent CWR22 and LNCaP xenograft tumors (Gregory et al. 2001a), or from increased activation of the AR promoter (Jarrard et al. 1998, Gregory et al. 2001b, Takahashi et al. 2002). Irrespective of the mechanism, after castration the concentration of AR protein in prostate tumors appears to be sufficient to allow continued AR signaling, particularly if tumor tissues retain significant concentrations of ligand as discussed above. In support of this hypothesis, increasing the AR concentration in prostate cancer cells using an AR-expressing lentivirus reduced the latency period for the development of $\mathrm{LNCaP}$ and LAPC4 xenograft tumors in castrate mice (Chen et al. 2004). An additional consequence in those studies was that 


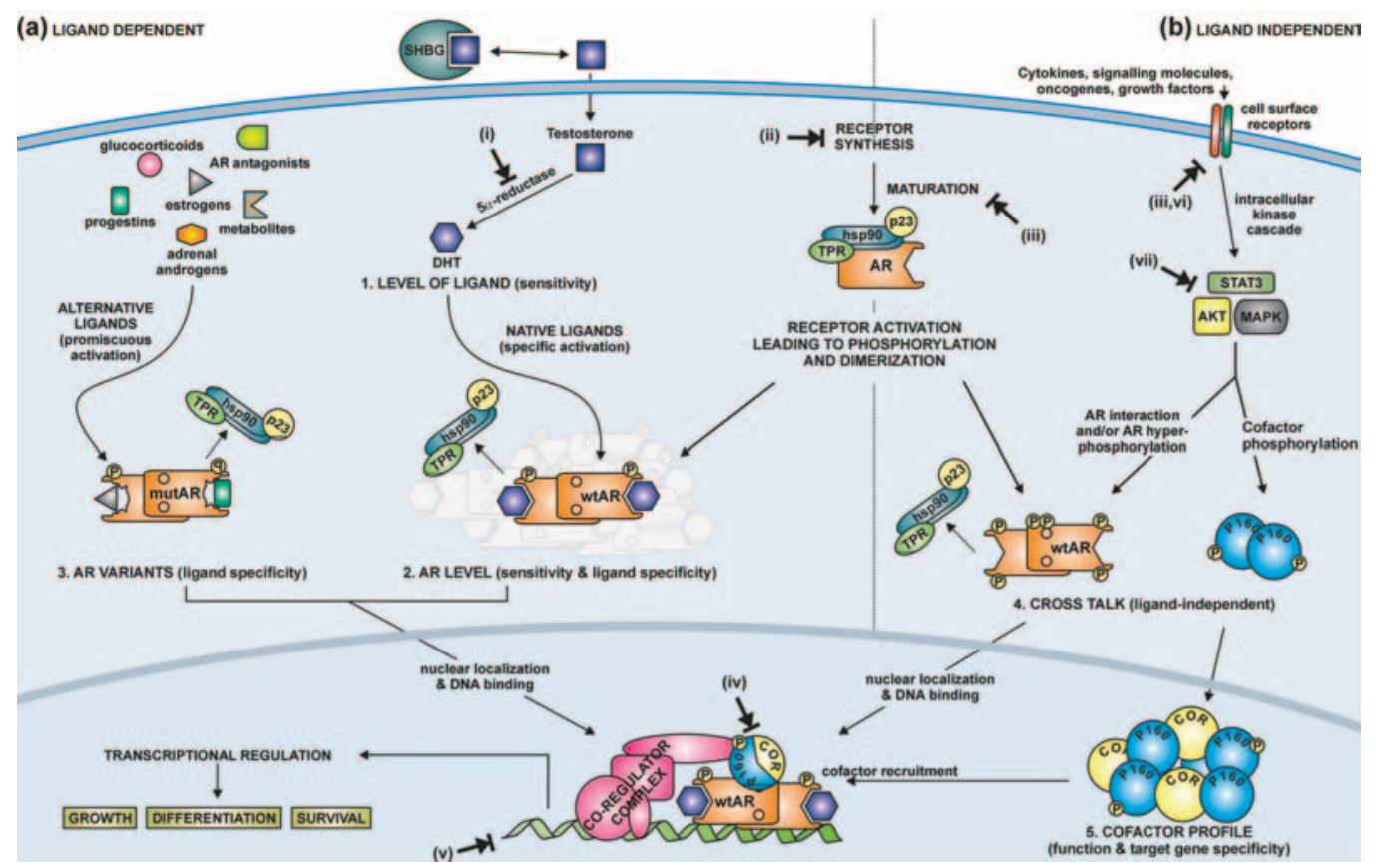

Figure 5 Signaling in castration-resistant prostate cancer and potential points of therapeutic intervention. After synthesis, the AR exists in dynamic equilibrium between an immature state and an active form capable of binding high-affinity androgenic ligands via association/dissociation with a complex that includes heat-shock proteins, p23 and a tetratricopeptide (TPR)-containing protein.

(a) Receptor-dependent, ligand-mediated signaling. Ligand binding results in the dissociation of this complex, receptor dimerization and phosphorylation, nuclear transport, DNA binding, the recruitment of components of the transcription machinery and other cofactor molecules, such as the p160 coactivators, and ultimately, the activation of particular gene pathways. (b) Receptor-dependent, ligand-independent signaling. The AR can also be activated in the absence of ligand by membrane-bound tyrosine kinase receptors such as HER2/neu, and by signaling molecules, growth factors and cytokines. Intracellular kinase cascades result in receptor activation, transport, binding to androgen response elements and the transactivation of target genes. 1-5. Mechanisms of continued androgen signaling implicated in maintaining prostate cancer growth in a castrate environment after androgen ablation therapy. 1. Tumor cells may acquire mechanisms to accumulate androgens, such as sequestration by steroid hormone binding globulin (SHBG) or altered regulation of enzymes involved in the synthesis and metabolism of androgens. 2. Castrate-resistant clinical prostate cancer samples often exhibit increased AR concentrations compared with early-stage tumors or normal prostate cells. This may result from amplification or overexpression of the $A R$ gene. 3. AR gene mutations can allow promiscuous activation of the AR by alternative ligands, such as glucocorticoids, estrogens, adrenal androgens, progestins and traditional receptor antagonists such as hydroxyflutamide. Other mutations may alter the recruitment of cofactors. 4. Cross-talk with other signaling pathways may activate the AR in the absence of native ligands. 5. An altered profile of AR coregulators (coactivators and corepressors) may facilitate ligand-independent AR signaling, or enhance AR activation by low levels of ligand. (i-vii). Potential points of therapeutic intervention: (i) $5 \alpha$-reductase inhibitors (e.g. finasteride, dutasteride); (ii) antisense AR oligonucleotides; (iii) Hsp90 inhibitors (e.g. 17allylaminogeldanamycin); (iv) AR inhibitors, antibodies, histone acetylase and deacetylase inhibitors (e.g. SAHA); (v) specific response element blockers (e.g. polyamides); (vi) growth factor receptor antibodies (e.g. herceptin); (vii) inhibitors of MAPK, the JAK-STAT pathway or Akt.

increased expression of $\mathrm{AR}$ reversed the antagonist function of bicalutamide such that it acted as a weak AR agonist (Chen et al. 2004). The precise consequences of increased expression of AR are not known, but recruitment and inactivation of pro-apoptotic factors by the AR can impair cell cycle arrest and apoptosis of prostate cancer cells (Li et al. 2003), suggesting that indirect mechanisms may, in part, facilitate survival of prostate cancer cells with higher concentrations of AR. The direct effects of increased AR concentrations probably derive from altered transcription of AR-responsive genes expressing products that are involved in both steroid biosynthesis and cell cycle control, apoptosis and differentiation (Nelson et al. 2002, Holzbeierlein et al. 2004).

\section{Structure and activation of the AR}

The AR protein has three major functional domains: a large amino-terminal domain (NTD) that contains at least two activation functions, AF-1 and AF-5; a DNAbinding domain (DBD); and a carboxy-terminal ligand binding domain (LBD) that contains a highly conserved 
(a)

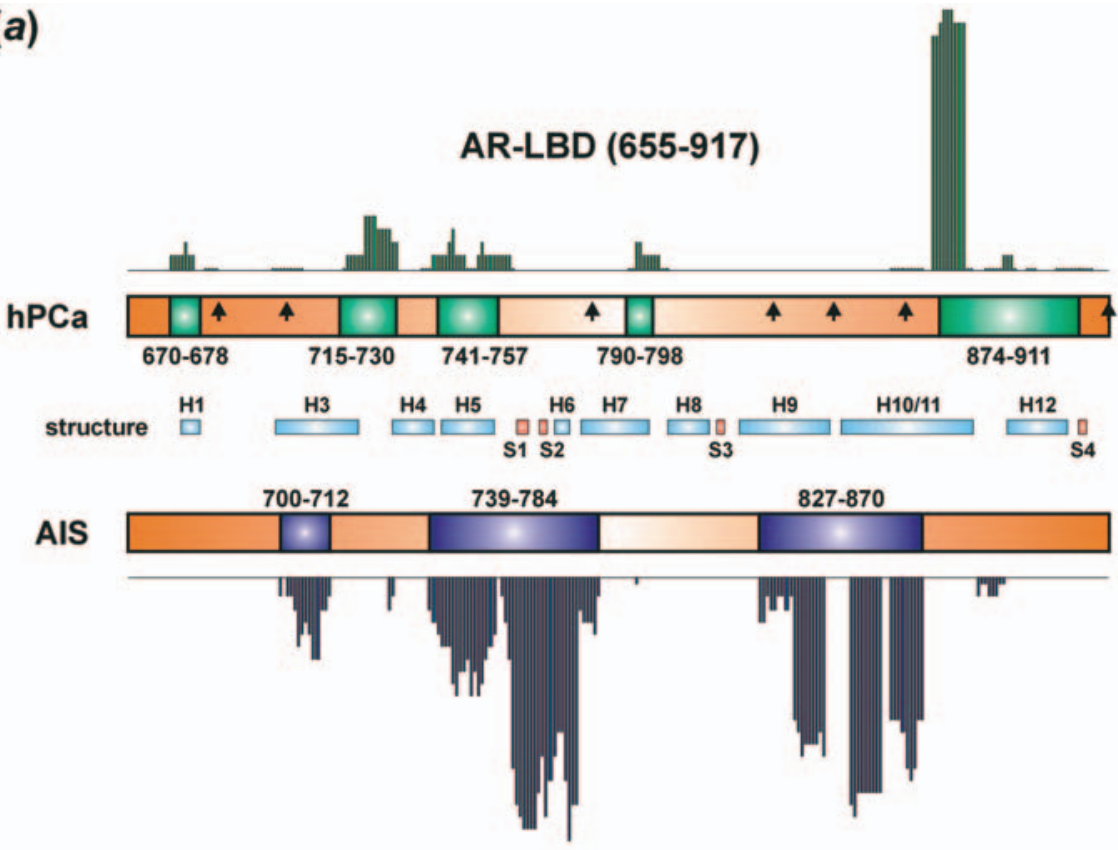

(b)

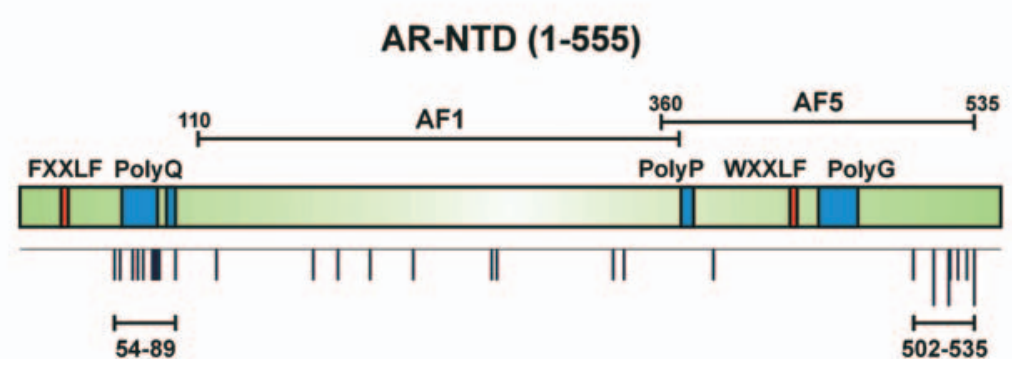

Figure 6 Collocation of $A R$ gene mutations in clinical prostate cancer. (a) The position and frequency of missense mutations identified in the AR LBD in human prostate cancer ( $\mathrm{hPCa}$ ) and the inherited from of androgen insensitivity (AIS) were used to calculate a proportional frequency distribution of mutations. Vertical bars represent the percentage of mutations identified in the AR LBD in either hPCa or AIS within a 9 amino acid region centered on individual codons. A cut-off of $4 \%$ was applied such that bars represent at least two mutations from prostate cancer within each 9 amino acid region. Areas of collocation in hPCa (green boxes) and AIS (blue boxes) were determined by delineating the actual position of mutations occurring in regions defined by the frequency distribution, and required a minimum of four independent mutations. The amino acid residues encompassing these regions are indicated. The arrows ( $\mathrm{hPCa}$ ) denote the seven locations of the eight of 57 missense mutations that do not fall within the indicated regions of collocation. (b) Schematic representation of the AR NTD showing position of key functional sub-domain structures (AF1, activation function 1; AF5, activation function 5; PolyQ, polyglutamine; PolyG, polyglycine), and the position and frequency (vertical bars) of somatic mutations identified in clinical prostate cancer. Two putative areas of collocation are indicated.

ligand-dependent transactivation function (AF-2). More than $85 \%$ of mutations detected in the AR LBD in clinical prostate cancer (Gottlieb et al. 1999), in addition to those identified in cell lines and animal models, collocate to a small number of discrete regions of the receptor (Fig. 6a) (Buchanan et al. 2001a,b). In all, 86\% of mutations in the LBD in prostate cancer and $72 \%$ of inactivating mutations in the AR identified in the inherited form of androgen insensitivity collocate to regions that collectively encompass only $10 \%$ and $11 \%$ of the AR coding sequence respectively (Fig. 6a). The regions of collocation in prostate cancer, with the exception of that encompassing amino acids 739-755, are distinct from those in androgen insensitivity and have been implicated in modulating the specificity of the ligand binding, cofactor responses and transactivation capacity of the receptor (Buchanan et al. $2000,2001 b$ ). It is hypothesized that, given the appropriate hormonal environment, mutations in these regions of collocation in prostate tumors facilitate increased AR function, resulting in a survival advantage. Although the 
Endocrine-Related Cancer (2004) 11 459-476

Table 1 Mutations detected in activation function 5 of the androgen receptor in clinical prostate cancer

\begin{tabular}{lll}
\hline Nucleotide change & Amino acid substitution & \\
\hline CCG $\rightarrow$ CTG & Pro389Leu & Reference \\
CCT $\rightarrow$ CTT & Pro502Leu & Taplin et al. 2001 \\
CCC $\rightarrow$ TCC & Pro512Ser & Tilley et al. unpublished \\
AGT $\rightarrow$ GGT & Ser513Gly & Hyytinen et al. 2002 \\
ATG $\rightarrow$ GTG & Met521Val & Tilley et al. unpublished \\
GGC $\rightarrow$ AGC & Gly522Ser & Tilley et al. unpublished \\
GGC $\rightarrow$ GAC & Gly522Asp & Hyytinen et al. 2002 \\
TGG $\rightarrow$ TAG & Trp524STOP & Hyytinen et al. 2002 \\
GAT $\rightarrow$ GGT & Asp526Gly & Hyytinen et al. 2002 \\
CCT $\rightarrow$ TCT & Pro531Ser & Tilley et al. 1996 \\
ATG $\rightarrow$ AGG & Met535Arg & Hyytinen et al. 2002 \\
ATG $\rightarrow$ GTG & Met535Val & Tilley et al. unpublished \\
& & Tilley et al. unpublished
\end{tabular}

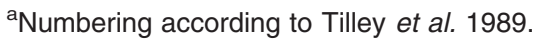

$A R$ gene mutation collocation data are currently less compelling for the AR NTD than for the LBD, only a few studies have examined the coding sequence of the AR NTD for mutations (Fig. 6b). This is particularly relevant to resolving conflicting reports of the frequency of $A R$ gene mutations in prostate cancer, as the findings of recent animal model and clinical studies suggest that surgical and medical castration result in the preferential accumulation of mutations in the AR NTD (Han et al. 2001, Hyytinen et al. 2002). Studies by Hyytenin and colleagues (2002) and our own unpublished work found that more than $50 \%$ of the AR gene mutations detected in cohorts of patients with prostate cancer receiving combined androgen blockade were located within a C-terminal 34 amino acid region (amino acids 502-535) of the AF-5 activation function in the NTD (Fig. 6b, Table 1). AR gene mutations that confer enhanced responsiveness to putative AR coregulators have also been identified in the AF-1 activation function (Han et al. 2001). One of these mutations (Glu231Gly), located in the highly conserved AR NTD signature sequence, is of particular interest, as enforced expression of the receptor variant in the mouse prostate confers rapid development of prostatic intraepithelial neoplasia that progresses to invasive and metastatic disease in $100 \%$ of mice ( $N$ Greenberg, personal communication). In contrast, enforced expression of the wild-type $A R$ has no observable effect on the prostate. The findings of that study highlight the potential functional significance of mutations in the AR NTD, and demonstrate that specific mutations can turn the $A R$ into a potent oncogene sufficient to promote metastatic prostate cancer.

\section{Level and function of AR coregulators}

High-affinity ligand binding causes conformational changes to the AR that result in the recruitment of coregulator proteins that act to enhance (coactivators) or repress (corepressors) receptor function. The p160 coregulators interact with activation functions in both the LBD and NTD of the AR to enhance the transactivation capacity of the receptor in the presence of the native ligand, DHT. Amplification, overexpression, or both, of p160 cofactors (such as TIF2 and SRC1) has been reported in human prostate cancers after the failure of AAT, and in castrate-resistant CWR22 xenografts (Anzick et al. 1997, Gregory et al. 2001b). In clinical studies, the concentrations of key AR coregulators, including p300/CBP, have been shown to increase after AAT (Debes et al. 2003). Overexpression of these coactivators increases AR transactivation capacity in the presence of physiological concentrations of non-classical ligands such as estradiol, progesterone and adrenal androgens (Gregory et al. 2001b). In addition, Yeh and colleagues (1998, 1999a) have shown that specific AR coregulators, namely ARA54, ARA55 and ARA70, selectively enhance the ability of $17 \beta$ estradiol, hydroxyflutamide and androst-5-ene-3 $\beta, 17 \beta$ diol, a precursor to testosterone, to activate the AR. Therefore, increased concentrations of AR coactivators in prostate tumors could contribute to continued AR signaling after androgen ablation, by sensitizing the receptor to lower concentrations of native androgens, or by altering the specificity of AR activation. A similar effect could be achieved by decreasing the concentrations of AR corepressors such as SMRT and NCoR, which inhibit AR function in a ligand-dependent manner (Cheng et al. 2002, Dotzlaw et al. 2002, Liao et al. 2002) and probably compete with p160 and other coactivators for the same interaction surfaces (G Buchanan \& W Tilley, unpublished observations). In support of this hypothesis, NCoR was recently shown to mediate the antagonist action of bicalutamide, flutamide and mifepristone for the AR in prostate cancer cells (Berrevoets et al. 2004). These observations suggest that the ratio of critical AR coregulators is likely to be a key determinant of AR function in prostate cancer cells. 


\section{Ligand-independent activation of the AR}

Studies using in vitro systems indicate that the AR can be activated in the absence of native ligand by growth factors (keratinocyte growth factor, insulin-like growth factor-1 and epidermal growth factor), cytokines (interleukin-6) or protein kinase-A, or by overexpression of the tyrosine kinase receptor, HER2/neu (Culig et al. 1994, Nazareth \& Weigel 1996, Craft et al. 1999, Yeh et al. 1999b, Grossmann et al. 2001, Ueda et al. 2002a,b, Gregory et al. 2004). Activation of the AR by these factors in the absence of ligand enhances transcription of PSA and other androgen-regulated genes (Yeh et al. 1999b), can enhance the proliferation of prostate cancer cells in vitro and in vivo (Lee et al. 2003) and increases tumor cell survival during androgen deprivation (Wen et al. 2000). These observations have led to the proposal that ligandindependent activation of the AR may facilitate continued prostate cancer growth after AAT, although more evidence that these signaling pathways are active in in vivo systems is required. In particular, the critical molecular events leading to activation of the $\mathrm{AR}$ in vivo by ligand-independent pathways in prostate cancer cells need to be defined precisely. For example, evolving data suggest that ligand-independent activation of the AR may result, in part, from modification of cofactors by phosphorylation (e.g. SRC1 by MAPK), which serves to create a more efficient platform for recruitment of the basal transcription complex (Rowan et al. 2000, Gregory et al. 2004).

The recent findings discussed above suggest that the growth of prostate tumors after the failure of conventional AAT is not necessarily a result of the evolution of a growth state that circumvents the androgen-signaling axis, but rather is the result of increased sensitivity to activation or increased activity of the AR in tumor cells. This represents a paradigm shift in the accepted understanding of what is commonly called hormone-refractory prostate cancer, and extends the understanding of the molecular mechanisms involved in disease progression. As each of the emerging pathways to AAT-resistant prostate cancer detailed above is dependent on the presence of functional AR, targeting the receptor itself potentially offers a more effective approach to treatment of this disease.

\section{Strategies for targeting the AR Reducing AR concentrations}

Various approaches, including double-stranded RNA interference (Caplen et al. 2002), antisense oligonucleotides (Eder et al. 2000, 2002), hammerhead ribozymes (Zegarra-Moro et al. 2002) and, more recently, the ansamycin antibiotic geldanamycin or its analog 17-allylamino-17-demethoxygeldanamycin (17-AAG) (Grenert et al. 1997, Prodromou et al. 1997, Stebbins et al. 1997, Solit et al. 2002) have been tested for their ability to reduce the concentrations of AR and suppress the proliferation of human prostate cancer cells both in vitro and in vivo (Solit et al. 2002, 2003). Phase II clinical trials of 17-AAG for the treatment of solid tumors are in progress. Although these approaches show promise as novel therapeutic agents for use in prostate cancer, all have the potential to disrupt androgen signaling in several tissues which, although not life-threatening, may cause debilitating side effects similar to those evoked by current hormonal treatments. In the case of 17-AAG, there is the added complication of specificity of action, as this agent will also suppress the functional maturation of other Hsp90 substrates, including Raf and HER2/neu, on which a range of cell types are dependent.

\section{Inhibiting AR function}

Based on AR variants deficient in autologous transactivation, dominant negative AR inhibitors provide a potentially effective approach to inhibition of endogenous AR function in prostate cancer cells (Palvimo et al. 1993). In a recent study, an AR inhibitor created by fusion of an AR deleted for the core region of AF-1 to the Kruppelassociated box transcriptional repressor domain was able to inhibit AR function significantly in human prostate cancer cells (Bramlett et al. 2001). However, as titration of cellular repressor complexes by the Kruppel-associated box transcriptional repressor domain may interfere with signaling by other pathways, and delivery of large expression constructs to cancer cells in vivo remains a significant challenge, the clinical usefulness of this particular AR inhibitor strategy is uncertain. In an alternative approach, we have generated small autologous human AR inhibitors, based on an AR inhibitor reported for the rat AR (Palvimo et al. 1993), by deletion of the majority of the AR NTD. These constructs have little or no intrinsic activity in the presence of androgen, but can inhibit more than $95 \%$ of the activity of wild-type AR and gain-of-function AR variants that are activated by either native androgens or non-classical ligands (L M Butler \& W D Tilley, unpublished observations). These AR inhibitors therefore have the potential to block ARdependent growth of prostate tumors irrespective of the level or structure of the receptor. Nonetheless, the success of this and other gene-based strategies depends in a large part on the development of suitable viral delivery approaches that specifically introduce AR inhibitor constructs into prostate cancer cells, or alternatively on the development of small-molecule inhibitors of AR function that are more amenable to therapeutic delivery and targeting. 
Microinjection of a commercially available antibody to the AR has been shown to inhibit AR function (Zegarra-Moro et al. 2002). Notably, the antibody suppressed the proliferation of androgen-sensitive and castrate-resistant prostate cancer cells that express the AR, reduced PSA concentrations and caused morphological changes indicative of differentiation (Zegarra-Moro et al. 2002). Transfection of a 'decoy' double-stranded DNA fragment containing an androgen response element into LNCaP cells was able to compete with endogenous androgen response elements for AR binding, and induce apoptosis of the cells in the presence of DHT (Kuratsukuri et al. 1999). However, delivery of these types of agents to prostate cancer cells in vivo currently is not feasible. Recently, the histone deacetylase inhibitors suberoylanilide hydroxamic acid and phenylbutyrate, which inhibit the activity of chromatin remodeling enzymes recruited by AR coregulators such as NCoR and SMRT (Marks et al. 2001), have been shown to suppress the growth of prostate cancer cells in vitro and in vivo (Butler et al. 2000, Gore \& Carducci 2000). These agents are currently being evaluated in a clinical setting for the treatment of various solid tumors, including prostate cancer (Carducci et al. 2001, Kelly et al. 2003).

Inhibition of the ligand-independent pathways leading to AR activation is a potentially viable alternative therapeutic strategy that may be best implemented in combination with strategies that target the AR directly. There are several inhibitors of the MAPK pathway currently undergoing clinical trial for treatment of cancer or inflammatory diseases (English \& Cobb 2002), and specific inhibitors of JAK or Akt kinases are in advanced stages of preclinical development (Mills et al. 2003, Luo \& Laaja 2004). In addition, agents such as the ansamycin antibiotics (discussed above) have the potential to target simultaneously both ligand-dependent and ligand-independent activities of AR by promoting degradation of both AR and HER2/neu (Solit et al. 2002).

\section{Selection pressures associated with AAT influence AR status}

There is emerging evidence that different mechanisms facilitating continued signaling through the AR in tumor cells may depend on the specific therapy to which a tumor has been exposed during treatment of the disease. Given the often protracted natural history of prostate cancer, and that treatments, both local and systemic, alone or in combination, are being administered earlier in the clinical course, we are now potentially creating a new series of diseases as a result of this selection. We have termed this 'therapy-mediated selection pressure'. This concept is exemplified by studies of the autochthonous transgenic adenocarcinoma of the mouse prostate (TRAMP) model of prostate cancer (Greenberg et al. 1995, Gingrich \& Greenberg 1996, Gingrich et al. 1996, 1997), in which androgen ablation results in the selection of $A R$ gene mutations in distinctly different regions of the receptor than in intact mice. In all, six of the eight AR gene mutations identified in tumors of intact TRAMP mice at 24-28 weeks of age were located in the AR LBD, whereas in mice castrated at 12 weeks, seven of seven $A R$ gene mutations identified in their recurrent tumors at 24-28 weeks of age were located in the AR NTD (Han et al. 2001).

The clinical importance of therapy-mediated selection pressure is illustrated by the syndrome of steroid hormone and anti-androgen withdrawal, which is characterized by tumor regression and decreasing serum concentrations of PSA when treatment with anti-androgens (flutamide, nilutamide and bicalutamide), estrogens (diethylstilbestrol) or progestational agents (megestrol acetate) is selectively discontinued at the time of clinical progression (Kelly \& Scher 1993, Scher \& Kelly 1993, Small \& Carroll 1994, Bissada \& Kaczmarek 1995, Dawson \& McLeod 1995, Nieh 1995, Small \& Srinivas 1995, Huan et al. 1997 , Kelly et al. 1997, Akakura et al. 1998, Kelly 1998). Another example is the greater proportional response to bicalutamide in patients previously treated with flutamide compared with those who did not receive this drug (Scher \& Kolvenbag 1997, Joyce et al. 1998).

Taplin and colleagues (1999) reported that the $A R$ from tumors of patients treated with hydroxyflutamide, as part of a combined androgen blockade strategy, harbored mutations that exhibited a marked increase in activity in response to hydroxyflutamide, but not to DHT or other androgenic ligands (Fenton et al. 1997). In contrast, $A R$ gene mutations in tumors from patients treated with orchidectomy or bicalutamide, or both (Haapala et al. 2001, Taplin et al. 2003), are located in different regions of the receptor. Recent clinical studies by us and others have determined that the majority of mutations identified in patients after complete androgen blockade are located in a discrete region of the AR NTD (see above, Structure and activation of the AR). These findings are consistent with specific alterations in AR signaling being selected for by different hormonal treatments.

In an attempt to minimize the potential detrimental effects of continuous AAT, we have begun pharmacological repletion of testosterone in a rapid hormonal cycling strategy. We hypothesize that this strategy will limit tumor regrowth between cycles while maintaining the sensitivity of prostate cancer cells to subsequent androgen withdrawal, resulting in a net decrease in tumor mass with each successive cycle. A 3:1 ratio of depletion and repletion is used. Conceptually, the approach mimics the female menstrual cycle, but does not allow for the equivalent of 


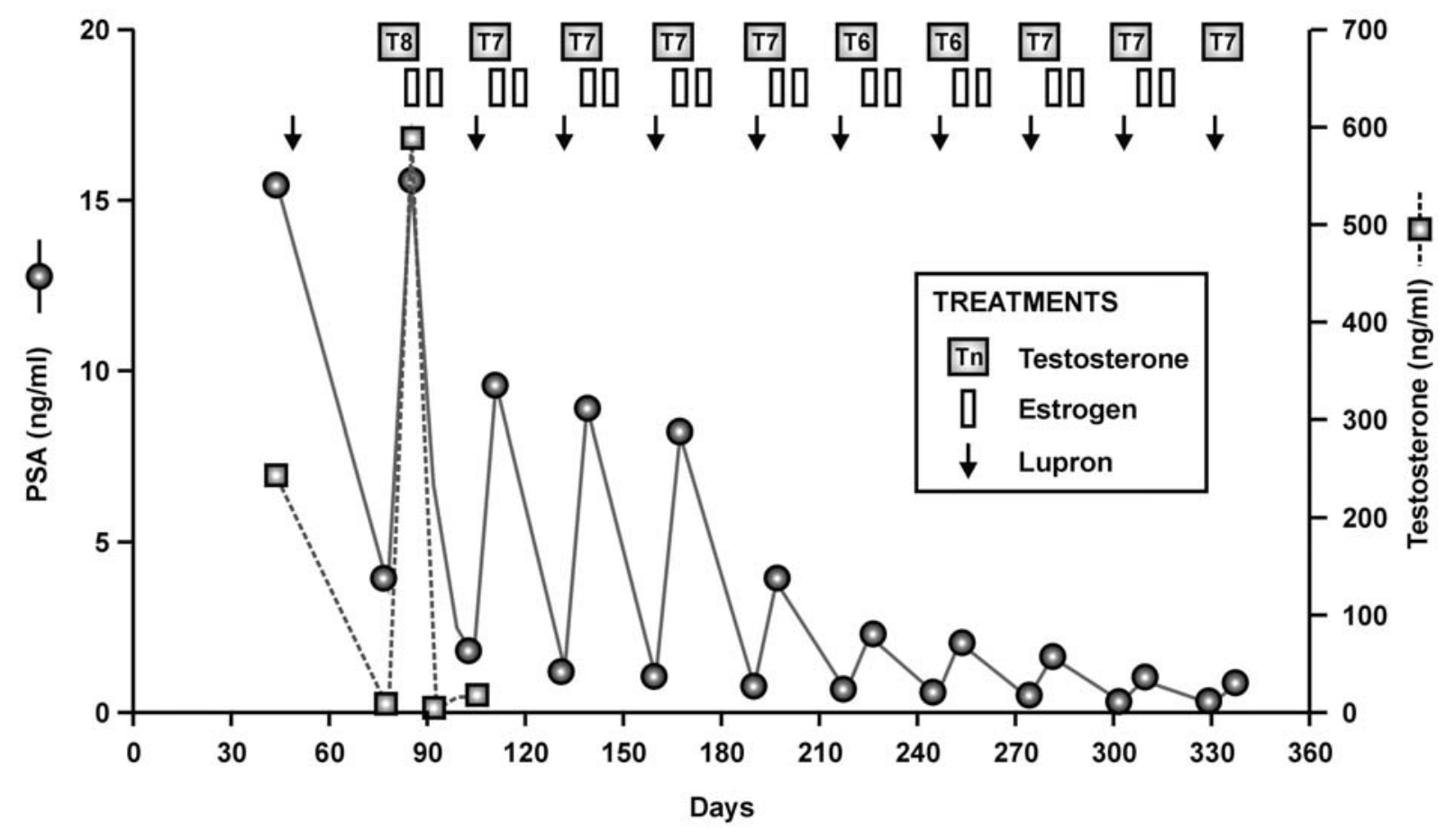

Figure 7 Rapid hormonal cycling. Serial PSA $(\bigcirc)$ and testosterone $(\square)$ concentrations in a patient treated with monthly GnRH analogs (Lupron) to induce a castrate state. Beginning on week 4, testosterone patches were administered for 1 week, followed by 2 weeks of estrogen, and 1 week of no treatment. Cycles were repeated monthly. Note the serial declines in the PSA peaks and troughs with sequential cycles.

a prolonged luteal phase to restore the endometrial lining to a fully functioning level. A representative case is illustrated in Fig. 7, showing successive declining peaks and troughs in serum PSA concentrations after administration of testosterone to a patient undergoing intermittent AAT. The effect of testosterone repletion on chemosensitivity is currently under study in a trial in which chemotherapy is given after a 7-day course of testosterone, following which the patches are withdrawn for a 3-week period and cycles are repeated.

\section{Implications}

To date, the general approach to the hormonal management of prostate cancer has been to administer AATs that predominantly target AR signaling by reducing circulating concentrations of ligand on a continuous basis, to observe the effect, and to administer an additional therapy when the first is no longer effective (i.e. when the tumor is regrowing). This scenario is illustrated by the CWR22 xenograft model of prostate cancer in Fig. 8. Second-line approaches, be they additional hormone treatments or cytotoxic drugs, are used after tumor progression on first-line therapy. The results of AAT studies with CWR22 prostate cancer xenografts led us to propose a functional time-course classification of the disease with potential points of therapeutic attack (Fig. 8). Alternative therapeutic approaches should be directed toward targeting the AR in addition to targeting the ligand, with the aim of completely inhibiting AR signaling, both in non-proliferating or dormant tumor cells (Fig. 8, points i, ii) and in proliferating cells (Fig. 8, point iii), thereby preventing or delaying the emergence of truly hormone-refractory disease. Until AR function can be completely abrogated, it will not be possible to say conclusively whether regrowth of prostate tumors after failure of AAT is strictly dependent on continued AR signaling, or is initiated by non-AR-dependent growth regulatory pathways.

On the basis of current evidence implicating the AR as a key factor in maintaining the growth of prostate cancer cells in an androgen-depleted state, receptor-targeted treatments should effectively eliminate AR-dependent prostate cancer cells. Moreover, different androgen-ablation and receptor-targeting therapies could be applied simultaneously to enhance the proportion of cells undergoing apoptotic cell death, or in a cyclical manner to limit selection of clones with a specific adaptation in the 


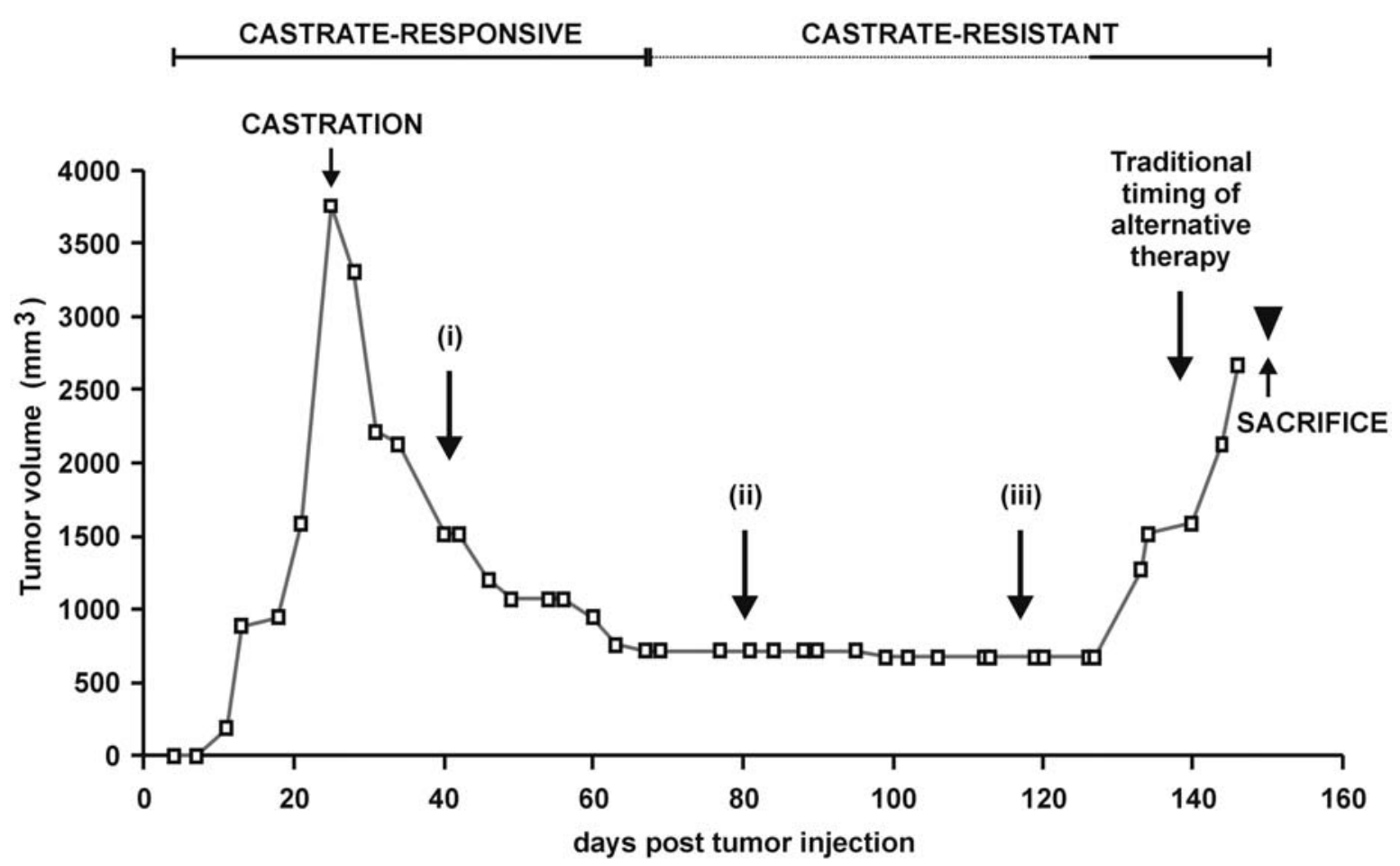

Figure 8 Timing and points of intervention. A functional time-course classification for combining different approaches with AAT (CASTRATION), based on changes in gene expression and regulatory proteins in CWR22 xenografts. Potential points of therapeutic attack: (i) non-proliferating tumor cells; (ii) dormant tumor cells; (iii) proliferating cells. Modified from Scher (2003).

androgen signaling pathway, thereby countering enhanced sensitivity of AR signaling and preventing tumor survival. The challenge, however, is to develop targeted strategies that completely knock out the AR in clinical prostate cancer without affecting other androgen target tissues. These approaches could improve quality of life, especially for those patients being treated earlier in the course of disease with AAT and who face the prospect of significant side effects, including bone and muscle loss, loss of libido and a range of psychosocial effects resulting from prolonged androgen ablation. Complete abrogation of AR signaling by application of both AAT and AR-targeted therapies at a time of low-volume disease before selection of tumor cells that can survive and grow in a castrate environment may afford the best opportunity to advance the management of prostate cancer since the concept of androgen ablation was introduced by Huggins, Stevens and Hodges more than 60 years ago (Huggins et al. 1941).

\section{Acknowledgements}

The authors would like to thank Professor Villis R Marshall for his critique of this manuscript. This work was supported by the MSKCC SPORE in Prostate
Cancer (H I S and W G), an award from the Prostate Cancer Foundation (to H I S and W G), the PepsiCo Foundation (H I S), the National Health and Medical Research Council of Australia (187641 and 299048 to W D T), the Cancer Council of South Australia and United States Department of Defense (W81XWH-04-1-0017 to G B). L B is a recipient of a Fellowship from the Prostate Cancer Foundation of Australia.

\section{References}

Agus DB, Cordon-Cardo C, Fox W, Drobnjak M, Koff A, Golde DW \& Scher HI 1999 Prostate cancer cell cycle regulators: response to androgen withdrawal and development of androgen independence. Journal of the National Cancer Institute 91 1869-1876.

Akakura K, Akimoto S, Furuya Y \& Ito H 1998 Incidence and characteristics of antiandrogen withdrawal syndrome in prostate cancer after treatment with chlormadinone acetate. European Urology 33 567-571.

Amler LC, Agus DB, LeDuc C, Sapinoso ML, Fox WD, Kern S, Lee D, Wang V, Leysens M, Higgins B, Martin J, Gerald W, Dracopoli N, Cordon-Cardo C, Scher HI \& Hampton GM 2000 Dysregulated expression of androgen-responsive and nonresponsive genes in the androgen-independent prostate 
cancer xenograft model CWR22-R1. Cancer Research $\mathbf{6 0}$ 6134-6141.

Anzick SL, Kononen J, Walker RL, Azorsa DO, Tanner MM, Guan XY, Sauter G, Kallioniemi OP, Trent JM \& Meltzer PS 1997 AIB1, a steroid receptor coactivator amplified in breast and ovarian cancer. Science 277 965-968.

Balk SP, Ko YJ \& Bubley GJ 2003 Biology of prostate-specific antigen. Journal of Clinical Oncology 21 383-391.

Bentel JM \& Tilley WD 1996 Androgen receptors in prostate cancer. Journal of Endocrinology 151 1-11.

Berrevoets CA, Umar A, Trapman J \& Brinkmann AO 2004 Differential modulation of androgen receptor transcriptional activity by the nuclear receptor corepressor (N-CoR). Biochemical Journal 379 1147-1154.

Bissada NK \& Kaczmarek AT 1995 Complete remission of hormone refractory adenocarcinoma of the prostate in response to withdrawal of diethylstilbestrol. Journal of Urology 153 1944-1945.

Bramlett KS, Dits NF, Sui X, Jorge MC, Zhu X \& Jenster G 2001 Repression of androgen-regulated gene expression by dominant negative androgen receptors. Molecular and Cellular Endocrinology 183 19-28.

Bubendorf L, Kononen J, Koivisto P, Schraml P, Moch H, Gasser TC, Willi N, Mihatsch MJ, Sauter G \& Kallioniemi OP 1999 Survey of gene amplifications during prostate cancer progression by high-throughout fluorescence in situ hybridization on tissue microarrays. Cancer Research $\mathbf{5 9}$ 803-806.

Buchanan G, Yang M, Nahm SJ, Han G, Moore N, Bentel JM, Matusik RJ, Horsfall DJ, Marshall VR, Greenberg NM \& Tilley WD 2000 Mutations at the boundary of the hinge and ligand binding domain of the androgen receptor confer increased transactivation function. Molecular Endocrinology 15 46-56.

Buchanan G, Irvine RA, Coetzee GA \& Tilley WD $2001 a$ Contribution of the androgen receptor to prostate cancer predisposition and progression. Cancer Metastasis Reviews 20 207-223.

Buchanan G, Greenberg NM, Scher HI, Harris JM, Marshall VR $\&$ Tilley WD 2001b Collocation of androgen receptor gene mutations in prostate cancer. Clinical Cancer Research 7 1273-1281.

Butler LM, Agus DB, Scher HI, Higgins B, Rose A, CordonCardo C, Thaler HT, Rifkind RA, Marks PA \& Richon VM 2000 Suberoylanilide hydroxamic acid, an inhibitor of histone deacetylase, suppresses the growth of prostate cancer cells in vitro and in vivo. Cancer Research 60 5165-5170.

Caplen NJ, Taylor JP, Statham VS, Tanaka F, Fire A \& Morgan RA 2002 Rescue of polyglutamine-mediated cytotoxicity by double-stranded RNA-mediated RNA interference. Human Molecular Genetics 11 175-184.

Carducci MA, Gilbert J, Bowling MK, Noe D, Eisenberger MA, Sinibaldi V, Zabelina Y, Chen TL, Grochow LB \& Donehower RC 2001 A phase I clinical and pharmacological evaluation of sodium phenylbutyrate on an 120-h infusion schedule. Clinical Cancer Research 7 3047-3055.

Chen CD, Welsbie DS, Tran C, Baek SH, Chen R, Vessella R, Rosenfeld MG \& Sawyers CL 2004a Molecular determinants of resistance to antiandrogen therapy. Nature Medicine $\mathbf{1 0}$ 33-39.

Cheng S, Brzostek S, Lee SR, Hollenberg AN \& Balk SP 2002 Inhibition of the dihydrotestosterone-activated androgen receptor by nuclear receptor corepressor. Molecular Endocrinology 16 1492-1501.

Chugh A, Ray A \& Gupta JB 2003 Squalene epoxidase as hypocholesterolemic drug target revisited. Progress in Lipid Research 42 37-50.

Craft N, Shostak Y, Carey M \& Sawyers CL 1999 A mechanism for hormone-independent prostate cancer through modulation of androgen receptor signaling by the HER-2/neu tyrosine kinase. Nature Medicine 5 280-285.

Culig Z, Hobisch A, Cronauer MV, Radmayr C, Trapman J, Hittmair A, Bartsch G \& Klocker H 1994 Androgen receptor activation in prostatic tumor cell lines by insulin-like growth factor-I, keratinocyte growth factor, and epidermal growth factor. Cancer Research 54 5474-5478.

Culig Z, Hobisch A, Hittmair A, Peterziel H, Cato AC, Bartsch G \& Klocker H 1998 Expression, structure, and function of androgen receptor in advanced prostatic carcinoma. Prostate 35 63-70.

Dawson NA \& McLeod DG 1995 Dramatic prostate specific antigen decrease in response to discontinuation of megestrol acetate in advanced prostate cancer: expansion of the antiandrogen withdrawal syndrome. Journal of Urology 153 1946-1947.

Debes JD, Sebo TJ, Lohse CM, Murphy LM, Haugen DA \& Tindall DJ 2003 p300 in prostate cancer proliferation and progression. Cancer Research 63 7638-7640.

Dotzlaw H, Moehren U, Mink S, Cato AC, Iniguez Lluhi JA \& Baniahmad A 2002 The amino terminus of the human AR is target for corepressor action and antihormone agonism. Molecular Endocrinology 16 661-673.

Eder IE, Culig Z, Ramoner R, Thurnher M, Putz T, NesslerMenardi C, Tiefenthaler M, Bartsch G \& Klocker H 2000 Inhibition of LncaP prostate cancer cells by means of androgen receptor antisense oligonucleotides. Cancer Gene Therapy 7 997-1007.

Eder IE, Hoffmann J, Rogatsch H, Schafer G, Zopf D, Bartsch G \& Klocker H 2002 Inhibition of LNCaP prostate tumor growth in vivo by an antisense oligonucleotide directed against the human androgen receptor. Cancer Gene Therapy 9 $117-125$.

English JM \& Cobb MH 2002 Pharmacological inhibitors of MAPK pathways. Trends in Pharmacological Sciences $\mathbf{2 3}$ 40-45.

Fenton MA, Shuster TD, Fertig AM, Taplin ME, Kolvenbag G, Bubley GJ \& Balk SP 1997 Functional characterization of mutant androgen receptors from androgen-independent prostate cancer. Clinical Cancer Research 3 1383-1388.

Fowler JE Jr \& Whitmore WF Jr 1981 The response of metastatic adenocarcinoma of the prostate to exogenous testosterone. Journal of Urology 126 372-375.

Geller J, Albert JD, Nachtsheim DA \& Loza D $1984 a$ Comparison of prostatic cancer tissue dihydrotestosterone levels at the time of relapse following orchiectomy or estrogen therapy. Journal of Urology 132 693-696. 
Geller J, de la Vega DJ, Albert JD \& Nachtsheim DA $1984 b$ Tissue dihydrotestosterone levels and clinical response to hormonal therapy in patients with advanced prostate cancer. Journal of Clinical Endocrinology and Metabolism 58 36-40.

Gelmann EP 2002 Molecular biology of the androgen receptor. Journal of Clinical Oncology 20 3001-3015.

Gingrich JR \& Greenberg NM 1996 A transgenic mouse prostate cancer model. Toxicologic Pathology 24 502-504.

Gingrich JR, Barrios RJ, Morton RA, Boyce BF, DeMayo FJ, Finegold MJ, Angelopoulou R, Rosen JM \& Greenberg NM 1996 Metastatic prostate cancer in a transgenic mouse. Cancer Research 56 4096-4102.

Gingrich JR, Barrios RJ, Kattan MW, Nahm HS, Finegold MJ \& Greenberg NM 1997 Androgen-independent prostate cancer progression in the TRAMP model. Cancer Research 57 4687-4691.

Gore SD \& Carducci MA 2000 Modifying histones to tame cancer: clinical development of sodium phenylbutyrate and other histone deacetylase inhibitors. Expert Opinion on Investigational Drugs 9 2923-2934.

Gottlieb B, Beitel LK, Lumbroso R, Pinsky L \& Trifiro M 1999 Update of the androgen receptor gene mutations database. Human Mutation 14 103-114.

Greenberg NM, DeMayo F, Finegold MJ, Medina D, Tilley WD, Aspinall JO, Cunha GR, Donjacour AA, Matusik RJ \& Rosen JM 1995 Prostate cancer in a transgenic mouse. PNAS 92 3439-3443.

Gregory CW, Hamil KG, Kim D, Hall SH, Pretlow TG, Mohler JL \& French FS 1998 Androgen receptor expression in androgen-independent prostate cancer is associated with increased expression of androgen-regulated genes. Cancer Research 58 5718-5724.

Gregory CW, Johnson RT, Mohler JL, French FS \& Wilson EM 2001a Androgen receptor stabilization in recurrent prostate cancer is associated with hypersensitivity to low androgen. Cancer Research 61 2892-2898.

Gregory CW, He B, Johnson RT, Ford OH, Mohler JL, French FS \& Wilson EM 2001b A mechanism for androgen receptormediated prostate cancer recurrence after androgen deprivation therapy. Cancer Research 61 4315-4319.

Gregory CW, Fei X, Ponguta LA, He B, Bill HM, French FS \& Wilson EM 2004 Epidermal growth factor increases coactivation of the androgen receptor in recurrent prostate cancer. Journal of Biological Chemistry 279 7119-7130.

Grenert JP, Sullivan WP, Fadden P, Haystead TA, Clark J, Mimnaugh E, Krutzsch H, Ochel HJ, Schulte TW, Sausville E, Neckers LM \& Toft DO 1997 The amino-terminal domain of heat shock protein 90 (hsp90) that binds geldanamycin is an ATP/ADP switch domain that regulates hsp90 conformation. Journal of Biological Chemistry 272 23843-23850.

Grossmann ME, Huang H \& Tindall DJ 2001 Androgen receptor signaling in androgen-refractory prostate cancer. Journal of the National Cancer Institute 93 1687-1697.

Haapala K, Hyytinen ER, Roiha M, Laurila M, Rantala I, Helin HJ \& Koivisto PA 2001 Androgen receptor alterations in prostate cancer relapsed during a combined androgen blockade by orchiectomy and bicalutamide. Laboratory Investigation 81 1647-1651.
Han G, Foster BA, Mistry S, Buchanan G, Harris JM, Tilley WD \& Greenberg NM 2001 Hormone status selects for spontaneous somatic androgen receptor variants that demonstrate specific ligand and cofactor dependent activities in autochthonous prostate cancer. Journal of Biological Chemistry 276 11204-11213.

Hobisch A, Culig Z, Radmayr C, Bartsch G, Klocker H \& Hittmair A 1995 Distant metastases from prostatic carcinoma express androgen receptor protein. Cancer Research $\mathbf{5 5}$ 3068-3072.

Holzbeierlein J, Lal P, LaTulippe E, Smith A, Satagopan J, Zhang L, Ryan C, Smith S, Scher H, Scardino P, Reuter V \& Gerald WL 2004 Gene expression analysis of human prostate carcinoma during hormonal therapy identifies androgenresponsive genes and mechanisms of therapy resistance. American Journal of Pathology 164 217-227.

Hryb DJ, Nakhla AM, Kahn SM, St George J, Levy NC, Romas NA \& Rosner W 2002 Sex hormone-binding globulin in the human prostate is locally synthesized and may act as an autocrine/paracrine effector. Journal of Biological Chemistry $27726618-26622$.

Huan SD, Gerridzen RG, Yau JC \& Stewart DJ 1997 Antiandrogen withdrawal syndrome with nilutamide. Urology 49 632-634.

Huggins C \& Hodges CV 1941 Studies on prostatic cancer: I. The effect of castration, of estrogen and of androgen injection on serum phosphatases in metastatic carcinoma of the prostate. Cancer Research 1 293-297.

Huggins C, Stevens RE \& Hodges CV 1941 Studies on prostatic cancer. II. The effect of castration on advanced carcinoma of the prostate gland. Archives of Surgery 43 209-228.

Hyytinen ER, Haapala K, Thompson J, Lappalainen I, Roiha M, Rantala I, Helin HJ, Janne OA, Vihinen M, Palvimo JJ \& Koivisto PA 2002 Pattern of somatic androgen receptor gene mutations in patients with hormone-refractory prostate cancer. Laboratory Investigation 82 1591-1598.

Jarrard DF, Kinoshita H, Shi Y, Sandefur C, Hoff D, Meisner LF, Chang C, Herman JG, Isaacs WB \& Nassif N 1998 Methylation of the androgen receptor promoter $\mathrm{CpG}$ island is associated with loss of androgen receptor expression in prostate cancer cells. Cancer Research 58 5310-5314.

Joyce R, Fenton MA, Rode P, Constantine M, Gaynes L, Kolvenbag G, DeWolf W, Balk S, Taplin ME \& Bubley GJ 1998 High dose bicalutamide for androgen independent prostate cancer: effect of prior hormonal therapy. Journal of Urology 159 149-153.

Kassouf W, Tanguay S \& Aprikian AG 2003 Nilutamide as second line hormone therapy for prostate cancer after androgen ablation fails. Journal of Urology 169 1742-1744.

Kelly WK 1998 Endocrine withdrawal syndrome and its relevance to the management of hormone refractory prostate cancer. European Urology 34 18-23.

Kelly WK \& Scher HI 1993 Prostate specific antigen decline after antiandrogen withdrawal: the flutamide withdrawal syndrome. Journal of Urology 149 607-609.

Kelly WK, Slovin S \& Scher HI 1997 Steroid hormone withdrawal syndromes. Pathophysiology and clinical significance. Urologic Clinics of North America 24 421-431. 
Kelly WK, Richon VM, O'Connor O, Curley T, MacGregorCurtelli B, Tong W, Klang M, Schwartz L, Richardson S, Rosa E, Drobnjak M, Cordon-Cordo C, Chiao JH, Rifkind R, Marks PA \& Scher H 2003 Phase I clinical trial of histone deacetylase inhibitor: suberoylanilide hydroxamic acid administered intravenously. Clinical Cancer Research 9 3578-3588.

Kim D, Gregory CW, French FS, Smith GJ \& Mohler JL 2002 Androgen receptor expression and cellular proliferation during transition from androgen-dependent to recurrent growth after castration in the CWR22 prostate cancer xenograft. American Journal of Pathology 160 219-226.

Koivisto PA \& Helin HJ 1999 Androgen receptor gene amplification increases tissue PSA protein expression in hormone-refractory prostate carcinoma. Journal of Pathology 189 219-223.

Koivisto P, Visakorpi T \& Kallioniemi OP 1996 Androgen receptor gene amplification: a novel molecular mechanism for endocrine therapy resistance in human prostate cancer. Scandinavian Journal of Clinical and Laboratory Investigation Supplementum 226 57-63.

Koivisto P, Kononen J, Palmberg C, Tammela T, Hyytinen E, Isola J, Trapman J, Cleutjens K, Noordzij A, Visakorpi T \& Kallioniemi OP 1997 Androgen receptor gene amplification: a possible molecular mechanism for androgen deprivation therapy failure in prostate cancer. Cancer Research $\mathbf{5 7}$ 314-319.

Kojima S, Suzuki H, Akakura K, Shimbo M, Ichikawa T \& Ito H 2004 Alternative antiandrogens to treat prostate cancer relapse after initial hormone therapy. Journal of Urology 171 679-683.

Kuratsukuri K, Sugimura K, Harimoto K, Kawashima H \& Kishimoto T 1999 'Decoy' of androgen-responsive element induces apoptosis in LNCaP cells. Prostate 41 121-126.

Labrie F, Dupont A, Belanger A, Lefebvre FA, Cusan L, Monfette G, Laberge JG, Emond JP, Raynaud JP, Husson JM \& Fazekas AT 1983 New hormonal treatment in cancer of the prostate: combined administration of an LHRH agonist and an antiandrogen. Journal of Steroid Biochemistry 19999 1007.

LaTulippe E, Satagopan J, Smith A, Scher H, Scardino P, Reuter V \& Gerald WL 2002 Comprehensive gene expression analysis of prostate cancer reveals distinct transcriptional programs associated with metastatic disease. Cancer Research 62 4499-4506.

Lee SO, Lou W, Hou M, De Miguel F, Gerber L \& Gao AC 2003 Interleukin-6 promotes androgen-independent growth in LNCaP human prostate cancer cells. Clinical Cancer Research 9 370-376.

Li P, Lee H, Guo S, Unterman TG, Jenster G \& Bai W 2003 AKT-independent protection of prostate cancer cells from apoptosis mediated through complex formation between the androgen receptor and FKHR. Molecular and Cellular Biology 23 104-118.

Liao G, Chen LY, Zhang A, Godavarthy A, Xia F, Ghosh JC, Li H \& Chen JD 2002 Regulation of androgen receptor activity by the nuclear receptor corepressor SMRT. Journal of Biological Chemistry 278 5052-5061.
Linja MJ, Savinainen KJ, Saramaki OR, Tammela TL, Vessella RL \& Visakorpi T 2001 Amplification and overexpression of androgen receptor gene in hormone-refractory prostate cancer. Cancer Research 61 3550-3555.

Luo C \& Laaja P 2004 Inhibitors of JAKs/STATs and the kinases: a possible new cluster of drugs. Drug Discovery Today 9 268-275.

Manni A, Bartholomew M, Caplan R, Boucher A, Santen R, Lipton A, Harvey H, Simmonds M, White-Hershey D \& Gordon R 1988 Androgen priming and chemotherapy in advanced prostate cancer: evaluation of determinants of clinical outcome. Journal of Clinical Oncology 6 1456-1466.

Marks P, Rifkind RA, Richon VM, Breslow R, Miller T \& Kelly WK 2001 Histone deacetylases and cancer: causes and therapies. Nature Reviews Cancer 1 194-202.

Mills GB, Kohn E, Lu Y, Eder A, Fang X, Wang H, Bast RC, Gray J, Jaffe R \& Hortobagyi G 2003 Linking molecular diagnostics to molecular therapeutics: targeting the PI3K pathway in breast cancer. Seminars in Oncology 30 93-104.

Mohler JL, Gregory CW, Ford OH III, Kim D, Weaver CM, Petrusz P, Wilson EM \& French FS 2004 The androgen axis in recurrent prostate cancer. Clinical Cancer Research $\mathbf{1 0}$ $440-448$.

Nagabhushan M, Miller CM, Pretlow TP, Giaconia JM, Edgehouse NL, Schwartz S, Kung HJ, Vere White RW, Gumerlock PH, Resnick MI, Amini SB \& Pretlow TG 1996 CWR22: the first human prostate cancer xenograft with strongly androgen-dependent and relapsed strains both in vivo and in soft agar. Cancer Research 56 3042-3046.

Nazareth LV \& Weigel NL 1996 Activation of the human androgen receptor through a protein kinase A signaling pathway. Journal of Biological Chemistry 271 19900-19907.

Nelson PS, Clegg N, Arnold H, Ferguson C, Bonham M, White J, Hood L \& Lin B 2002 The program of androgen-responsive genes in neoplastic prostate epithelium. PNAS 99 11890-11895.

Nieh PT 1995 Withdrawal phenomenon with the antiandrogen casodex. Journal of Urology 153 1070-1072.

Palvimo JJ, Kallio PJ, Ikonen T, Mehto M \& Janne OA 1993 Dominant negative regulation of trans-activation by the rat androgen receptor: roles of the N-terminal domain and heterodimer formation. Molecular Endocrinology 7 1399-1407.

Pertschuk LP, Macchia RJ, Feldman JG, Brady KA, Levine M, Kim DS, Eisenberg KB, Rainford E, Prins GS \& Greene GL 1994 Immunocytochemical assay for androgen receptors in prostate cancer: a prospective study of 63 cases with longterm follow-up. Annals of Surgical Oncology 1 495-503.

Pretlow TG, Wolman SR, Micale MA, Pelley RJ, Kursh ED, Resnick MI, Bodner DR, Jacobberger JW, Delmoro CM \& Giaconia JM 1993 Xenografts of primary human prostatic carcinoma. Journal of the National Cancer Institute $\mathbf{8 5}$ 394-398.

Prins GS, Sklarew RJ \& Pertschuk LP 1998 Image analysis of androgen receptor immunostaining in prostate cancer accurately predicts response to hormonal therapy. Journal of Urology 159 641-649. 
Prodromou C, Roe SM, O’Brien R, Ladbury JE, Piper PW \& Pearl LH 1997 Identification and structural characterization of the ATP/ADP-binding site in the Hsp90 molecular chaperone. Cell 90 65-75.

Rowan BG, Weigel NL \& O'Malley BW 2000 Phosphorylation of steroid receptor coactivator-1. Identification of the phosphorylation sites and phosphorylation through the mitogen-activated protein kinase pathway. Journal of Biological Chemistry 275 4475-4483.

Sadi MV \& Barrack ER 1993 Image analysis of androgen receptor immunostaining in metastatic prostate cancer. Heterogeneity as a predictor of response to hormonal therapy. Cancer 71 2574-2580.

Scher HI 2003 Prostate carcinoma: defining therapeutic objectives and improving overall outcomes. Cancer 97 758-771.

Scher HI \& Kelly WK 1993 Flutamide withdrawal syndrome: its impact on clinical trials in hormone-refractory prostate cancer. Journal of Clinical Oncology 11 1566-1572.

Scher HI \& Kolvenbag GJ 1997 The antiandrogen withdrawal syndrome in relapsed prostate cancer. European Urology 31 3-7.

Scher HI, Steineck G \& Kelly WK 1995 Hormone-refractory (D3) prostate cancer: refining the concept. Urology $\mathbf{4 6}$ 142-148.

Small EJ 1997 Re: Characterization of patients with androgen independent prostatic carcinoma whose serum prostate specific antigen decreased following flutamide withdrawal [letter; comment]. Journal of Urology 158552.

Small EJ \& Carroll PR 1994 Prostate-specific antigen decline after casodex withdrawal: evidence for an antiandrogen withdrawal syndrome. Urology 43 408-410.

Small EJ \& Srinivas S 1995 The antiandrogen withdrawal syndrome. Experience in a large cohort of unselected patients with advanced prostate cancer. Cancer 76 1428-1434.

Solit DB, Zheng FF, Drobnjak M, Munster PN, Higgins B, Verbel D, Heller G, Tong W, Cordon-Cardo C, Agus DB, Scher HI \& Rosen N 2002 17-Allylamino-17-

demethoxygeldanamycin induces the degradation of androgen receptor and HER-2/neu and inhibits the growth of prostate cancer xenografts. Clinical Cancer Research 8 986-993.

Solit DB, Scher HI \& Rosen N 2003 Hsp90 as a therapeutic target in prostate cancer. Seminars in Oncology 30 709-716.

Stebbins CE, Russo AA, Schneider C, Rosen N, Hartl FU \& Pavletich NP 1997 Crystal structure of an Hsp90geldanamycin complex: targeting of a protein chaperone by an antitumor agent. Cell 89 239-250.

Takahashi S, Inaguma S, Sakakibara M, Cho YM, Suzuki S, Ikeda Y, Cui L \& Shirai T 2002 DNA methylation in the androgen receptor gene promoter region in rat prostate cancers. Prostate 52 82-88.

Takeda H, Akakura K, Masai M, Akimoto S, Yatani R \& Shimazaki J 1996 Androgen receptor content of prostate carcinoma cells estimated by immunohistochemistry is related to prognosis of patients with stage D2 prostate carcinoma. Cancer 77 934-940.

Tan J, Sharief Y, Hamil KG, Gregory CW, Zang DY, Sar M, Gumerlock PH, deVere WR, Pretlow TG, Harris SE, Wilson EM, Mohler JL \& French FS 1997 Dehydroepiandrosterone activates mutant androgen receptors expressed in the androgen-dependent human prostate cancer xenograft CWR22 and LNCaP cells. Molecular Endocrinology 11 450-459.

Taplin ME, Bubley GJ, Ko YJ, Small EJ, Upton M, Rajeshkumar B \& Balk SP 1999 Selection for androgen receptor mutations in prostate cancers treated with androgen antagonist. Cancer Research 59 2511-2515.

Taplin ME, Halabi S, Rajeshkuman B, $\mathbf{M}^{\mathrm{c}}$ Quain L, Wooda BA, Picus J, Hayes DF, Volgelzang NJ \& Small EJ 2001 Androgen receptor mutations in androgen independent prostate cancer (AIPCA) do not correlate with anti-androgen withdrawal response. Proceedings of the American Society of Clinical Oncology 37th Annual Meeting, San Francisco, CA, USA. Abstract 4862.

Taplin ME, Rajeshkumar B, Halabi S, Werner CP, Woda BA, Picus J, Stadler W, Hayes DF, Kantoff PW, Vogelzang NJ \& Small EJ 2003 Androgen receptor mutations in androgen-independent prostate cancer: Cancer and Leukemia Group B Study 9663. Journal of Clinical Oncology 21 2673-2678.

Tilley WD, Marcelli M, Wilson JD \& McPhaul 1989 Characterisation and expression of a cDNA encoding the human androgen receptor. PNAS 86 327-331.

Tilley WD, Lim-Tio SS, Horsfall DJ, Aspinall JO, Marshall VR \& Skinner JM 1994 Detection of discrete androgen receptor epitopes in prostate cancer by immunostaining: measurement by color video image analysis. Cancer Research $\mathbf{5 4}$ 096-4102.

Tilley WD, Buchanan G, Hickey TE \& Bentel JM 1996 Mutations in the androgen receptor gene are associated with progression of human prostate cancer to androgen independence. Clinical Cancer Research 2 277-285.

Tilley WD, Buchanan G \& Coetzee GA 2003 Androgen receptor signaling in prostate cancer. In Hormones Genes and Cancer, pp 288-315. Eds BE Henderson, BA Ponder \& RK Ross. New York: Oxford University Press.

Ueda T, Bruchovsky N \& Sadar MD 2002a Activation of the androgen receptor $\mathrm{N}$-terminal domain by interleukin-6 via MAPK and STAT3 signal transduction pathways. Journal of Biological Chemistry 277 7076-7085.

Ueda T, Mawji NR, Bruchovsky N \& Sadar MD $2002 b$ Ligandindependent activation of the androgen receptor by interleukin- 6 and the role of steroid receptor coactivator- 1 in prostate cancer cells. Journal of Biological Chemistry 277 38087-38094.

Wainstein MA, He F, Robinson D, Kung HJ, Schwartz S, Giaconia JM, Edgehouse NL, Pretlow TP, Bodner DR \& Kursh ED 1994 CWR22: androgen-dependent xenograft model derived from a primary human prostatic carcinoma. Cancer Research 54 6049-6052.

Wen Y, Hu MC, Makino K, Spohn B, Bartholomeusz G, Yan DH \& Hung MC 2000 HER-2/neu promotes androgenindependent survival and growth of prostate cancer cells through the Akt pathway. Cancer Research 60 6841-6845.

Wirth MP \& Froschermaier SE 1997 The antiandrogen withdrawal syndrome. Urological Research 25 S67-S71. 
Yeh S, Miyamoto H, Shima H \& Chang C 1998 From estrogen to androgen receptor: a new pathway for sex hormones in prostate. PNAS 95 5527-5532.

Yeh S, Kang HY, Miyamoto H, Nishimura K, Chang HC, Ting HJ, Rahman M, Lin HK, Fujimoto N, Hu YC, Mizokami A, Huang KE \& Chang C 1999a Differential induction of androgen receptor transactivation by different androgen receptor coactivators in human prostate cancer DU145 cells. Endocrine 11 195-202.
Yeh S, Lin HK, Kang HY, Thin TH, Lin MF \& Chang C 1999b From HER2/Neu signal cascade to androgen receptor and its coactivators: a novel pathway by induction of androgen target genes through MAP kinase in prostate cancer cells. PNAS 96 5458-5463.

Zegarra-Moro OL, Schmidt LJ, Huang H \& Tindall DJ 2002 Disruption of androgen receptor function inhibits proliferation of androgen-refractory prostate cancer cells. Cancer Research 62 1008-1013. 